\title{
Technical note: Assessment of milk temperature measured by automatic milking systems as an indicator of body temperature and fever in dairy cows
}

\author{
A. Pohl, W. Heuwieser, ${ }^{1}$ and O. Burfeind \\ Clinic of Animal Reproduction, Faculty of Veterinary Medicine, Freie Universität Berlin, Königsweg 65, 14163 Berlin, Germany
}

\begin{abstract}
The objective of this study was to evaluate whether milk temperature (MT) measured by automatic milking system (AMS) is a reliable indicator of body temperature of dairy cows and whether cows with fever could be detected. Data loggers (Minilog 8, Vemco Ltd., Halifax, NS, Canada) measuring body temperature were inserted for $7 \pm 1 \mathrm{~d}$ into the vaginal cavity of 31 dairy cows and programmed to take 1 reading/min. Milk temperature was recorded at each milking event by the AMS, and values from the vaginal loggers were paired with the corresponding MT. The correlation (r) between vaginal temperature (VT) and MT was 0.52 . Vaginal temperature was higher $\left(39.1 \pm 0.4^{\circ} \mathrm{C}\right)$ than MT $(38.6$ $\pm 0.7^{\circ} \mathrm{C}$ ) with a mean difference of $0.5 \pm 0.6^{\circ} \mathrm{C}$. The ability of MT to identify cows with fever was assessed using 2 approaches. In the first approach, VT could indicate fever at any time of the day, whereas MT could display fever only during the milking events of a given day. Different definitions of fever based on thresholds of VT and duration exceeding these thresholds were constructed. Different thresholds of MT were tested to distinguish between cows with and without fever. The combination of $39.0^{\circ} \mathrm{C}$ as a threshold for $\mathrm{MT}$ and $39.5^{\circ} \mathrm{C}$ for at least $2 \mathrm{~h} / \mathrm{d}$ as a threshold for VT resulted in the highest combination of sensitivity (0.65) and specificity (0.65). In the second approach, we evaluated whether MT could identify cows with fever at a given milking event. A threshold of $\mathrm{MT}>38.7^{\circ} \mathrm{C}$ delivered the best combination of sensitivity (0.77) and specificity (0.66) when fever was defined as VT $\geq 39.5^{\circ} \mathrm{C}$. Therefore, MT measured by AMS can be indicative of fever in dairy cows to a limited extent.
\end{abstract}

Key words: automatic milking system, milk temperature, vaginal temperature, rectal temperature, fever

Received January 30, 2014.

Accepted March 23, 2014.

${ }^{1}$ Corresponding author: w.heuwieser@fu-berlin.de

\section{Technical Note}

Automatic milking systems (AMS) have become increasingly common since their appearance in 1992 in the Netherlands, especially in northwestern Europe, where $90 \%$ of the world's AMS farms are located (Svennersten-Sjaunja and Pettersson, 2008; de Koning, 2010). Dairy farms in North America and Japan are also increasingly utilizing AMS (de Koning, 2010). In 2012, more than 16,000 farms had adopted AMS for their daily milking routine worldwide (de Koning, 2013). The most common reasons for dairy farmers to invest in AMS are potential savings in labor, increased milk yields due to increased milking frequency, and a better social life for dairy farm families (Dijkhuizen et al., 1997; Wagner-Storch and Palmer, 2003; de Koning, 2010; Jacobs and Siegford, 2012). Using AMS, the focus of the traditional farm management shifts from the daily milking routine to a system reliant on new technology (Jacobs and Siegford, 2012).

One emerging challenge is to identify sick cows because the direct contact between personnel and cows during the daily milking routine is minimized. On the other hand, data of cows and milk (e.g., amount of milk, color, conductivity) generated during each milking event are promptly available and can be used for health assessments. In particular, the health status of postpartum cows should be monitored carefully because numerous diseases such as metritis, mastitis, and metabolic disorders occur primarily in the postpartum period (Smith and Risco, 2005). In health monitoring programs, the most commonly used parameter to identify sick cows is the measurement of rectal temperature (RT; Smith and Risco, 2005).

One option the AMS provides is the measurement of the milk temperature (MT) for each cow during every milking event. In earlier studies, temperature sensors were integrated into the short piece of the milk tube for measurement of MT and comparison with body temperature (BT). The results showed that the correlation between MT and BT ranged from $\mathrm{r}=0.78$ to $\mathrm{r}=0.99$ (Igono et al., 1987; Fordham et al., 1988; West et al., 1990, 1999). Based on these findings, it is 
plausible to use MT measured with the AMS to detect cows susceptible for diseases.

Therefore, the overall objective of this study was to investigate whether MT measured by an AMS is a reliable indicator of BT in dairy cows. Specifically, the objectives were (1) to determine the relationship (correlation and difference) between MT and BT; (2) to determine a threshold for MT to detect cows with fever considering different definitions of fever on a particular day; and (3) to determine a threshold for MT to detect cows with fever considering different definitions of fever on a particular milking event.

\section{Data Collection}

Between March and May 2013, 31 lactating early postpartum (DIM 5 to 15) Holstein dairy cows (parity $2.2 \pm 1.0$ ) were enrolled on a commercial dairy farm in Brandenburg, Germany, that housed a total of 315 cows with an average 305-d milk production of 7,269 $\mathrm{kg}$ (3.55\% fat and $3.29 \%$ protein). Cows were housed indoors in a naturally ventilated freestall barn with cubicles equipped with rubber mats. Lactating cows were separated into 2 groups and each group was milked by 2 AMS (Lely, Astronaut 4, Maassluis, the Netherlands) in free cow traffic.

To measure BT of dairy cows continuously, data loggers inserted into the vaginal cavity have been used in several studies (Suthar et al., 2011, 2012; Burfeind et al., 2012). This approach has been validated recently (Vickers et al., 2010; Suthar et al., 2013) and demonstrated that differences between $\mathrm{RT}$ and vaginal temperature (VT) were negligible. In the current study, VT was recorded at 1-min intervals using microprocessor-controlled temperature loggers (Minilog 8, Vemco Ltd., Halifax, NS, Canada) attached to modified vaginal controlled internal drug release (CIDR) inserts. Data loggers $($ size $=92 \mathrm{~mm} \times 20 \mathrm{~mm}$; weight $=40.5$ g) were inserted into the vaginal cavity of postpartum cows (DIM 5 to 15$)$ for a $7( \pm 1)$-d period as previously described (Vickers et al., 2010).

Milk temperatures were recorded during each milking event by the AMS. Sensors inside the arm of the robot measured MT of each quarter individually. The milk flowed through the teat cups and an approximately 20-cm-long milk tube before it reached the sensor. At the end of each milking event, the highest MT measured during the whole milking process, irrespective of the quarter, was recorded and stored in the database of the proprietary software of the AMS (T4C, Lely) for later use by the herdsman.

Three cows were excluded from the study due to the complete loss of loggers. Therefore, data from 28 cows were used for final analyses. Four cows lost their loggers before the end of the 7-d interval, but data of the first days could be used until temperature fell below $38.0^{\circ} \mathrm{C}$, indicating the time of loss of the logger (Vickers et al., 2010). Overall, 1,037 of 240,664 measures of VT (0.4\%) were $<38.0^{\circ} \mathrm{C}$ and excluded from analyses. In total, 418 milking events had paired values of MT and VT.

Because the results of previous studies were inconsistent in the difference between MT and BT, a sample size calculation could not be conducted in advance. Instead, a post hoc power analysis was performed using G*Power (version 3.1.3, University of Düsseldorf, Düsseldorf, Germany) to verify the analysis of the difference between MT and VT in this study. The post hoc power analysis was applied with $\alpha=0.05$, sample size $=418$, and effect size $=0.83$. The power of analysis $(1-\beta)$ for the difference between MT and VT was 1.0.

\section{Relationship Between MT and VT}

Data from temperature loggers (VT) and the AMS software (MT) were downloaded into Excel spreadsheets (Office 2010, Microsoft Deutschland GmbH, Munich, Germany). Data included one MT for each milking event and several corresponding VT for the duration of each milking event. Values from the vaginal loggers were averaged for the minutes $(7.1 \pm 2.4)$ the cow was milked in the AMS and paired with the corresponding MT. Data were analyzed using IBM SPSS Statistics (version 20.0, IBM, Munich, Germany) and Medcalc (version 12.4.0.0, Mariakerke, Belgium). The difference and relationship between VT and MT was evaluated using a paired $t$-test and Pearson correlation. Furthermore, a Bland-Altman plot was generated displaying the average of VT and MT on the x-axis against the difference of VT and MT on the y-axis.

The correlation between VT and MT was $\mathrm{r}=0.52$ ( $\mathrm{n}=418 ; P<0.01)$. Vaginal temperature was higher $\left(39.1 \pm 0.4^{\circ} \mathrm{C}, \mathrm{n}=418\right)$ than $\mathrm{MT}\left(38.6 \pm 0.7^{\circ} \mathrm{C}, \mathrm{n}=\right.$ $418)$ with a mean difference of $0.5 \pm 0.6^{\circ} \mathrm{C}(\mathrm{n}=418 ; P$ $<0.01$, Figure 1).

Previous studies have showed inconsistent results in the difference between MT and BT. In our study, MT was about $0.5^{\circ} \mathrm{C}$ lower than VT. This is in agreement with older findings (Fordham et al., 1988) that described a $0.34^{\circ} \mathrm{C}$ lower MT measured with a temperature sensor at the top of each short milk tube than VT measured with a temperature probe. We assume that the lower MT was caused by the passage through the teat cups and milk tubes before reaching the sensors located in the arm of the AMS. In this way, MT might have cooled before it was measured. In contrast, Bitman et al. (1984) found a high correlation of temperatures $(r=$ 0.98 to 0.99 ) with negligible differences (body and udder temperatures were $38.8^{\circ} \mathrm{C} \pm 0.1^{\circ} \mathrm{C}$ ). Those authors, 


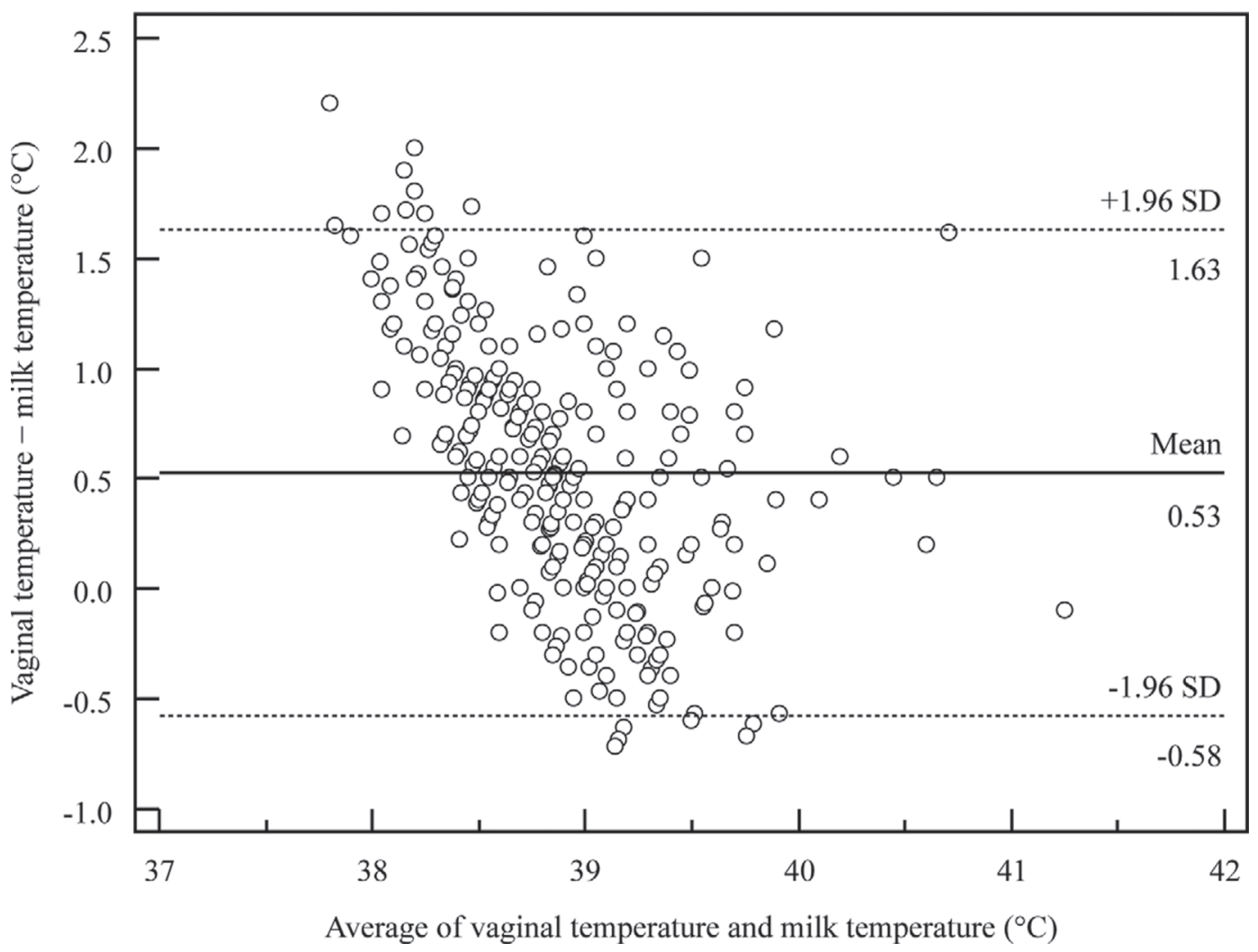

Figure 1. Bland-Altman plot showing the average of vaginal temperature and milk temperature on the $\mathrm{x}$-axis against the difference of vaginal and milk temperature on the y-axis. Vaginal temperature was higher $\left(39.1 \pm 0.4^{\circ} \mathrm{C}, \mathrm{n}=418\right)$ than milk temperature $\left(38.6 \pm 0.7^{\circ} \mathrm{C}, \mathrm{n}=418\right)$ with a mean difference of $0.5 \pm 0.6^{\circ} \mathrm{C}(\mathrm{n}=418, P<0.01)$.

however, implanted temperature sensors into the udder and the peritoneal cavity of lactating cows and thus excluded a cooling effect of the milk flowing from the udder to the sensor. West et al. (1999) recorded MT at each milking with a temperature sensor in the short piece of the milk tube of each milker and compared it with RT taken with a digital thermometer and found that MT was, on average, $0.15^{\circ} \mathrm{C}$ higher than RT. They did not, however, describe the penetration depth of the thermometer into the rectum, which has been shown to affect RT by as much as $0.4^{\circ} \mathrm{C}$ (Burfeind et al., 2010), or the distance between teat cup and temperature sensor in the milk tube.

Standard deviation of the mean difference of VT and MT was $\pm 0.6^{\circ} \mathrm{C}$. The Bland-Altman plot (Figure 1) displays the distribution of differences between VT and MT. The 95\% confidence interval reached from $-0.58^{\circ} \mathrm{C}$ to $+1.63^{\circ} \mathrm{C}$, showing the lower and upper limits of difference. Considering this rather wide range makes interpretation of MT more difficult. One possible explanation could be that the milk yield per milking or flow rate of the milk and temperature of the tubes could have affected the temperature of the milk reaching the sensors.
The Pearson correlation coefficient between MT and VT in this study $(\mathrm{r}=0.52 ; P<0.01)$ was lower than reported in previous studies for traditional milking equipment and BT ranging from 0.78 to 0.89 (Fordham et al., 1988; West et al., 1990, 1999). There is, however, no scientific reference for MT measured by an AMS compared with BT of lactating dairy cows. Different amounts of milk and different temperature of teat cups and milk tubes depending on the ambient temperature could affect the correlation between MT and VT. On the other hand, it is important to remember that no ideal benchmark exists to measure BT (Bewley et al., 2008). Each method has its own errors, such as insertion depth of the thermometer for RT, location of sensors for MT, and the correct position of vaginal loggers for VT. Any comparison of these methods will reflect these errors on both sides of the equation (Bewley et al., 2008).

\section{Fever Detection by AMS on a Particular Day}

To evaluate whether MT could identify cows with fever on a particular day using VT as gold standard, VT and MT did not have to measure fever simultaneously. 
Vaginal temperature could display fever at any time of the day, whereas MT could display fever only during the milking events of a given day. Different thresholds of fever to distinguish between healthy cows and cows suffering from an infectious disease have been described in the literature (Sheldon et al., 2006; Benzaquen et al., 2007; Wagner et al., 2007). Moreover, Burfeind et al. (2012) found that during hot periods, $28 \%$ of healthy cows exhibited $\mathrm{RT} \geq 39.5^{\circ} \mathrm{C}$, which might suggest that a higher threshold should be used in hot periods. Accordingly, 6 definitions of fever based on different thresholds of $\mathrm{VT}$ and durations exceeding these thresholds were constructed $\left(\geq 39.5^{\circ} \mathrm{C}\right.$ for $\geq 2, \geq 4$, and $\geq 8 \mathrm{~h} ; \geq 40.0^{\circ} \mathrm{C}$ for $\geq 2, \geq 4$, and $\geq 8 \mathrm{~h}$ ). Using these definitions of fever as gold standard, the ability of 4 different values of MT $\left(\geq 38.0^{\circ} \mathrm{C}, \geq 38.5^{\circ} \mathrm{C}, \geq 39.0^{\circ} \mathrm{C}, \geq 39.5^{\circ} \mathrm{C}\right)$ were tested to distinguish between cows with fever and cows without fever. Based on hourly VT means calculated from sixty 1-min values, cows were identified as being within 1 of the 6 fever categories on a given day and classified as 0 (no fever) or 1 (fever), respectively. Values from the AMS software were checked for each cow and day for the occurrence of fever for the 4 different thresholds based on MT. If MT was higher than a fever threshold during at least one milking event per day, values for that day were classified as 1 (fever). If MT remained below the fever threshold, they were classified as 0 (no fever). These classifications of fever based on VT and MT were paired for each day, resulting in a total of 185 paired cow days. Values of VT were used as gold standard and combined with MT values in $2 \times 2$ tables. The ability to distinguish between fever and no fever was expressed as sensitivities (Se), specificities $(\mathbf{S p})$, positive predictive values $(+\mathbf{P V})$, and negative predictive values $(-\mathbf{P V})$. Cases where both MT and VT displayed fever were considered true positives (TP) and cases where MT failed to indicate fever were considered false negative (FN). True negatives (TN) represented occasions when both MT and VT did not indicate fever, and cases where cows without fever (VT) were classified as cows with fever using MT were considered false positives (FP). Sensitivity is the percentage of cows with fever that were classified correctly by MT $[\mathrm{TP} /(\mathrm{TP}+\mathrm{FN}) \times 100]$; Sp is the percentage of cows without fever that were classified correctly by $\mathrm{MT}[\mathrm{TN} /(\mathrm{FP}+\mathrm{TN}) \times 100] ;+\mathrm{PV}$ is the percentage of cows that were correctly identified with fever by MT of the total of cows classified with fever by MT $[\mathrm{TP} /$ $(\mathrm{TP}+\mathrm{FP}) \times 100]$; and $-\mathrm{PV}$ is the percentage of cows correctly identified without fever by MT of the total of cows classified without fever by $\mathrm{MT}[\mathrm{TN} /(\mathrm{TN}+\mathrm{FN})$ $\times 100$ ] (Norberg et al., 2004).

Sensitivities, Sp, +PV, and -PV for the ability of MT to distinguish between cows with and without fever on a particular day $(\mathrm{n}=185)$ defined by VT are given in Table 1. With an increasing threshold for MT, Se decreased and Sp increased for all definitions of fever. The combination of $39.0^{\circ} \mathrm{C}$ as a threshold for MT and $39.5^{\circ} \mathrm{C}$ for at least $2 \mathrm{~h} / \mathrm{d}$ as a threshold for VT resulted in the highest combination of Se (0.65) and Sp (0.65).

This finding is plausible as the average MT was $0.5^{\circ} \mathrm{C}$ lower than VT, as mentioned above. This means that $65 \%$ of all cows with VT-registered fever were identified correctly by the AMS, and that $65 \%$ of all cows without fever were identified correctly. To explain the low Se, we evaluated how many cows with fever at any time of the day $\left(\mathrm{VT} \geq 39.5^{\circ} \mathrm{C}, \geq 2 \mathrm{~h}\right)$ also had fever (VT $\geq 39.5^{\circ} \mathrm{C}$ ) during milking events. This was the case in only $36.5 \%$ of all milking events. Moreover, many studies have showed that BT of dairy cattle exhibits a diurnal rhythm characterized by a minimum in the morning and a peak in the evening that lags 2 to $5 \mathrm{~h}$ behind peak ambient temperatures (Bitman et al., 1984; Kendall and Webster, 2009). Furthermore, Burfeind et al. (2012) found that VT is influenced by several factors such as DIM, time of day, and climate. In this study, cows chose freely when to go to the AMS and consequently BT was influenced by the time of day the cow was milked. On the other hand, cows showed fever only for at least $2 \mathrm{~h} / \mathrm{d}$ to be classified as "cow with fever" for the whole day. Accordingly, the likelihood that the cow went to the AMS in a period of no fever was rather high. Further research is warranted to study the lying and standing behavior of cows with fever and to determine if cows prefer to lie down and not go to the AMS during a period of fever.

\section{Fever Detection by AMS During a Particular Milking Event}

To evaluate if MT could identify cows with fever during a particular milking event, VT and MT had to measure fever simultaneously at that particular milking event. Values from the vaginal loggers were averaged for the minutes the cow was milked in the AMS (7.1 \pm 2.4) and paired with the corresponding MT. Values for VT were transformed into 1 (fever at that particular milking event) or 0 (no fever at that particular milking event) for 2 thresholds $\left(\geq 39.5^{\circ} \mathrm{C}\right.$ and $\left.\geq 40.0^{\circ} \mathrm{C}\right)$. The ability of MT to identify cows with fever at each milking event was examined using receiver-operating characteristic (ROC) analysis for both VT thresholds. The continuous variable was MT and the classification variable was the occurrence of fever measured by $\mathrm{VT}$ for $\geq 39.5^{\circ} \mathrm{C}$ or $\geq 40.0^{\circ} \mathrm{C}$. The ROC analysis involves calculating Se and Sp for different thresholds for MT and plots sensitivity on the $\mathrm{x}$-axis against ( 1 - specificity) on the y-axis. The closer the ROC curve is to the left 
Table 1. Test characteristics for different thresholds of milk temperature to identify cows with fever on a particular day $(\mathrm{n}=185)$ considering different definitions of fever based on thresholds of vaginal temperature and duration exceeding these thresholds considering vaginal temperature as gold standard

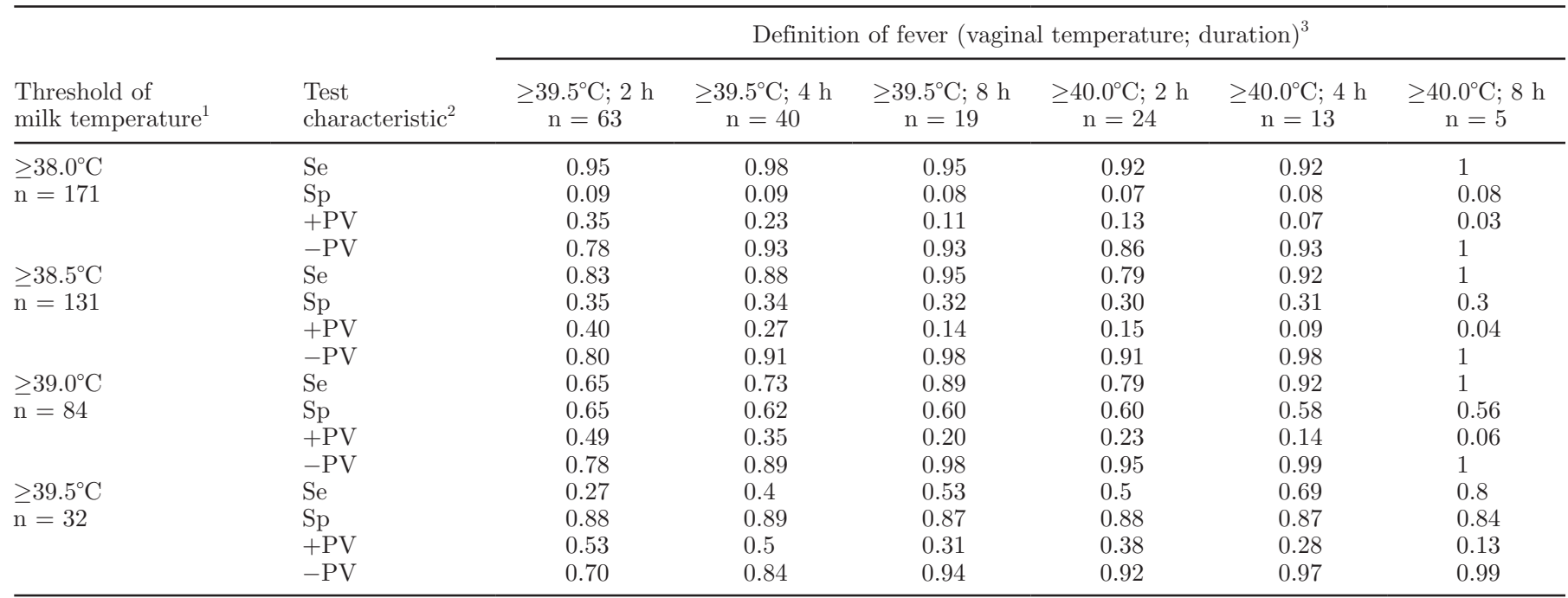

${ }^{1}$ Where $\mathrm{n}=$ number of days milk temperature reached a certain threshold in at least at one milking event per day.

${ }^{2} \mathrm{Se}=$ sensitivity, $\mathrm{Sp}=$ specificity, $+\mathrm{PV}=$ positive predictive value, $-\mathrm{PV}=$ negative predictive value.

${ }^{3}$ Where $\mathrm{n}=$ number of days vaginal temperature reached a certain definition of fever.

corner, the greater the accuracy of differentiation between cows with or without fever (Greiner et al., 2000). The area under the ROC curve (AUC) is a measure of the overall diagnostic accuracy of the measure tested. The AUC would be 1 if MT could perfectly distinguish between cows with and without fever based on VT and 0.5 if MT could not distinguish at all between the 2 groups. A $P$-value $<0.01$ and AUC $>0.5$ would demonstrate that MT could distinguish between cows with and without fever. The Youden Index is calculated as $(\mathrm{Se}+\mathrm{Sp}-1)$ for all thresholds of MT. The threshold of MT with highest Youden Index shows the value of MT with the best combination of Se and Sp.

The results of the $\mathrm{ROC}$ analysis to determine test characteristics to identify cows with fever on a particular milking event are given in Table 2. The Youden Index for both definitions of fever for $\mathrm{VT}\left(\geq 39.5^{\circ} \mathrm{C}\right.$, $\geq 40.0^{\circ} \mathrm{C}$ ) was highest for $\mathrm{MT}>38.7^{\circ} \mathrm{C}$ (Figure 2). The

Table 2. Test characteristics for different thresholds of milk temperature to identify cows with fever during a particular milking event; different definitions of fever based on thresholds of vaginal temperature were used considering vaginal temperature at the time of milking as gold standard

\begin{tabular}{|c|c|c|c|}
\hline \multirow[b]{2}{*}{$\begin{array}{l}\text { Threshold of } \\
\text { milk temperature }\end{array}$} & \multirow[b]{2}{*}{$\begin{array}{l}\text { Test } \\
\text { characteristic }^{1}\end{array}$} & \multicolumn{2}{|c|}{ Vaginal temperature $^{2}$} \\
\hline & & $\begin{array}{l}\geq 39.5^{\circ} \mathrm{C} \\
\mathrm{n}=57\end{array}$ & $\begin{array}{l}\geq 40.0^{\circ} \mathrm{C} \\
\mathrm{n}=18\end{array}$ \\
\hline \multirow[t]{4}{*}{$>38.0^{\circ} \mathrm{C}$} & $\mathrm{Se}$ & 1.00 & 1.00 \\
\hline & $\mathrm{Sp}$ & 0.28 & 0.19 \\
\hline & $+\mathrm{PV}$ & 0.17 & 0.05 \\
\hline & $-\mathrm{PV}$ & 1.00 & 1.00 \\
\hline \multirow[t]{4}{*}{$>38.7^{\circ} \mathrm{C}$} & Se & 0.77 & 1.00 \\
\hline & $\mathrm{Sp}$ & 0.66 & 0.63 \\
\hline & $+\mathrm{PV}$ & 0.26 & 0.11 \\
\hline & $-\mathrm{PV}$ & 0.95 & 1.00 \\
\hline \multirow{6}{*}{$>39.0^{\circ} \mathrm{C}$} & Se & 0.60 & 0.78 \\
\hline & Sp & 0.81 & 0.78 \\
\hline & $+\mathrm{PV}$ & 0.33 & 0.14 \\
\hline & $-\mathrm{PV}$ & 0.93 & 0.99 \\
\hline & Area under the curve & 0.79 & 0.90 \\
\hline & $(95 \%$ CI $)(P<0.01)$ & $(0.75-0.83)$ & $(0.86-0.92)$ \\
\hline
\end{tabular}

${ }^{1} \mathrm{Se}=$ sensitivity, $\mathrm{Sp}=$ specificity, $+\mathrm{PV}=$ positive predictive value, $-\mathrm{PV}=$ negative predictive value.

${ }^{2}$ Where $\mathrm{n}=$ number of milkings with vaginal temperature displaying fever $\left(\geq 39.5^{\circ} \mathrm{C}\right.$ or $\left.\geq 40.0^{\circ} \mathrm{C}\right)$. 

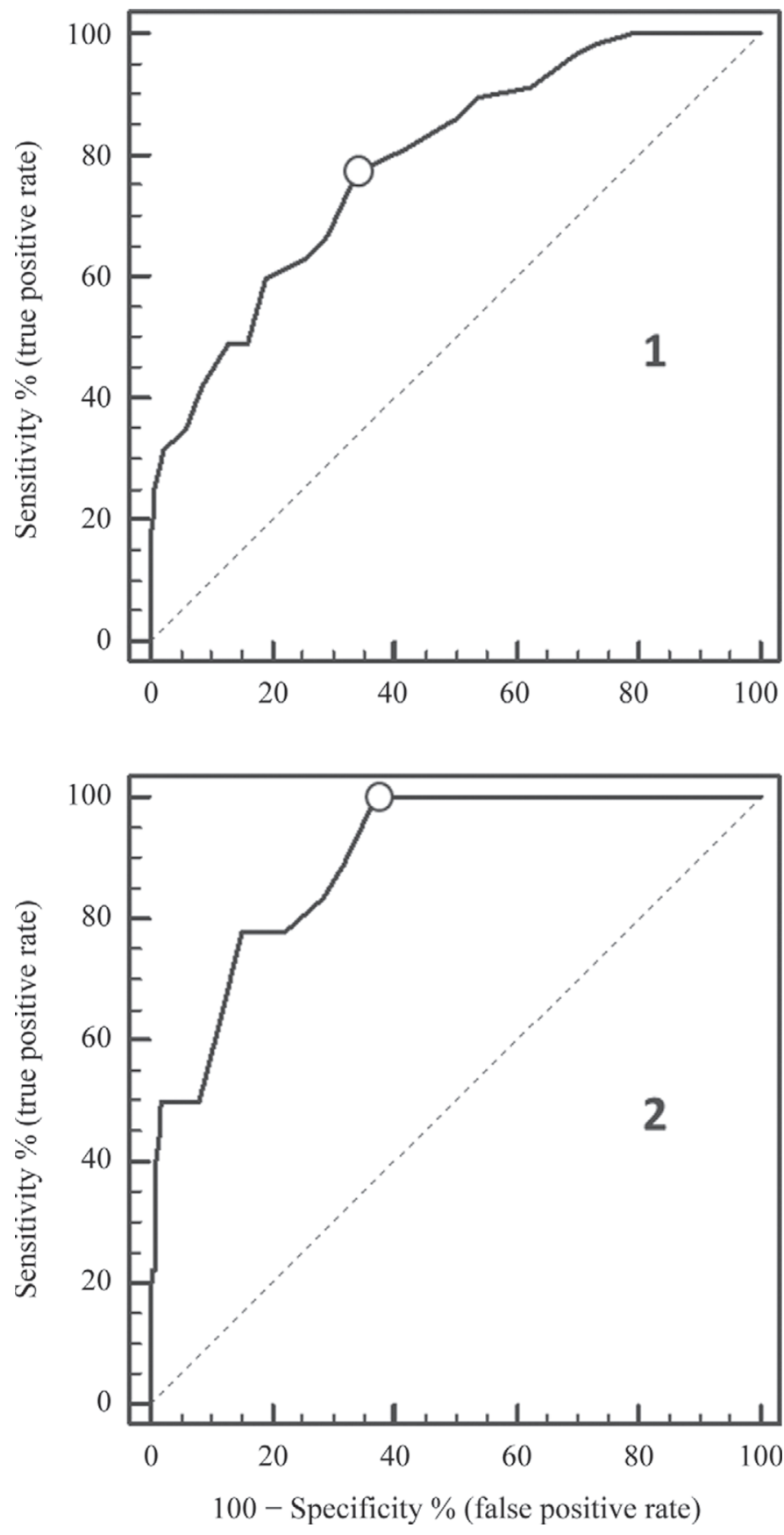

Figure 2. Receiver-operating characteristic (ROC) curve showing the false positive rate on the $\mathrm{x}$-axis and the true positive rate on the $\mathrm{y}$-axis for milk temperature (MT) as test parameter with vaginal temperature as gold standard defining fever as $\geq 39.5^{\circ} \mathrm{C}$ with area under the curve $=0.79(1)$ and $\geq 40.0^{\circ} \mathrm{C}$ with area under the curve $=0.90$ (2). Point with highest Youden Index $(\bigcirc)$ is shown in (1) and (2) with MT $>38.7^{\circ} \mathrm{C}$ for both vaginal temperature thresholds.

AUC for $\mathrm{VT} \geq 39.5^{\circ} \mathrm{C}$ and $\geq 40.0^{\circ} \mathrm{C}$ were 0.79 and 0.90 , respectively.

A threshold of $\mathrm{MT}>38.7^{\circ} \mathrm{C}$ delivered the highest combination of Se (0.77) and Sp (0.66) when fever was defined as $\mathrm{VT} \geq 39.5^{\circ} \mathrm{C}$. For $\mathrm{VT} \geq 40.0^{\circ} \mathrm{C}$ and $\mathrm{MT}$ $>38.7^{\circ} \mathrm{C}$, Se was 1 and Sp was 0.63 . Considering a VT above $40.0^{\circ} \mathrm{C}$ as fever, all cows were found correctly by the AMS, but the FP rate was $37 \%$. The result for the higher threshold should be interpreted with caution, because it is only based on 18 matched pairs of VT and MT.

In conclusion, MT measured by an AMS can be indicative of fever in dairy cows postpartum to a limited extent. Milk temperature thresholds of $>38.7^{\circ} \mathrm{C}$ or $\geq 39.0^{\circ} \mathrm{C}$ should be used to identify cows with fever at each milking event or for any time of day. Identified cows should be checked for other signs of systemic illness. Overall, MT should be interpreted with great caution because of high FP and FN rates.

\section{ACKNOWLEDGMENTS}

We gratefully thank the farm personnel of the dairy farm for the kind cooperation. Furthermore, we thank the staff of the Clinic of Reproduction, Freie Universiät (Berlin, Germany) for their support during the practical part of the study. Alina Pohl was partly funded by Tiergyn e.V. (Berlin, Germany).

\section{REFERENCES}

Benzaquen, M. E., C. A. Risco, L. F. Archbald, P. Melendez, M. J Thatcher, and W. W. Thatcher. 2007. Rectal temperature, calving-related factors, and the incidence of puerperal metritis in postpartum dairy cows. J. Dairy Sci. 90:2804-2814.

Bewley, J. M., M. E. Einstein, M. W. Grott, and M. M. Schutz. 2008. Comparison of reticular and rectal core body temperatures in lactating dairy cows. J. Dairy Sci. 91:4661-4672.

Bitman, J., A. Lefcourt, D. L. Wood, and B. Stroud. 1984. Circadian and ultradian temperature rhythms of lactating dairy cows. J. Dairy Sci. 67:1014-1023.

Burfeind, O., V. S. Suthar, and W. Heuwieser. 2012. Effect of heat stress on body temperature in healthy early postpartum dairy cows. Theriogenology 78:2031-2038.

Burfeind, O., M. A. G. von Keyserlingk, D. M. Weary, D. M. Veira, and W. Heuwieser. 2010. Short communication: Repeatability of measures of rectal temperature in dairy cows. J. Dairy Sci. 93:624-627.

de Koning, K. 2010. Automatic milking - Common practice on dairy farms. Pages V59-V63 in Proc. Second North Am. Conf. Robotic Milking, Toronto, Canada. Precision Dairy Operators, Elora, Canada.

de Koning, K. 2013. Developments in machine milking: Past and future. Pages 5-9 in Proc. 4. Tänikoner Melktechniktagung, Switzerland. Agroscope, Ettenhausen, Switzerland.

Dijkhuizen, A. A., R. B. M. Huirne, S. B. Harsh, and R. W. Gardner. 1997. Economics of robot application. Comput. Electron. Agric. $17: 111-121$

Fordham, D. P., P. Rowlinson, and T. T. McCarthy. 1988. Oestrus detection in dairy cows by milk temperature measurement. Res. Vet. Sci. 44:366-374.

Greiner, M., D. Pfeiffer, and R. D. Smith. 2000. Principles and practical application of the receiver-operating characteristic analysis for diagnostic tests. Prev. Vet. Med. 45:23-41.

Igono, M. O., H. D. Johnson, B. J. Steevens, G. F. Krause, and M. D. Shanklin. 1987. Physiological, productive, and economic benefits of shade, spray, and fan system versus shade for Holstein cows during summer heat. J. Dairy Sci. 70:1069-1079. 
Jacobs, J. A., and J. M. Siegford. 2012. Invited review: The impact of automatic milking systems on dairy cow management, behavior, health, and welfare. J. Dairy Sci. 95:2227-2247.

Kendall, P. E., and J. R. Webster. 2009. Season and physiological status affects the circadian body temperature rhythm of dairy cows. Livest. Sci. 125:155-160.

Norberg, E., H. Hogeveen, I. R. Korsgaard, N. C. Friggens, K. H. M. N. Sloth, and P. Løvendahl. 2004. Electrical conductivity of milk: Ability to predict mastitis status. J. Dairy Sci. 87:1099-1107.

Sheldon, I. M., G. S. Lewis, S. LeBlanc, and R. O. Gilbert. 2006. Defining postpartum uterine disease in cattle. Theriogenology 65:1516-1530.

Smith, B. I., and C. A. Risco. 2005. Management of periparturient disorders in dairy cattle. Vet. Clin. North Am. Food Anim. Pract. 21:503-521.

Suthar, V., O. Burfeind, S. Bonk, R. Voigtsberger, C. Keane, and W. Heuwieser. 2012. Factors associated with body temperature of healthy Holstein dairy cows during the first 10 days in milk. J. Dairy Res. 79:135-142.

Suthar, V., O. Burfeind, B. Maeder, and W. Heuwieser. 2013. Agreement between rectal and vaginal temperature measured with temperature loggers in dairy cows. J. Dairy Res. 80:240-245.

Suthar, V. S., O. Burfeind, J. S. Patel, A. J. Dhami, and W. Heuwieser. 2011. Body temperature around induced estrus in dairy cows. J. Dairy Sci. 94:2368-2373.
Svennersten-Sjaunja, K. M., and G. Pettersson. 2008. Pros and cons of automatic milking in Europe. J. Anim. Sci. 86:37-46.

Vickers, L. A., O. Burfeind, M. A. G. von Keyserlingk, D. M. Veira, D. M. Weary, and W. Heuwieser. 2010. Technical note: Comparison of rectal and vaginal temperatures in lactating dairy cows. J. Dairy Sci. 93:5246-5251.

Wagner, S. A., D. E. Schimek, and F. C. Cheng. 2007. Body temperature and white blood cell count in dairy cows during the first ten days after calving. Page 233 in Proc. Am. Assoc. Bovine Pract., Stillwater, OK. Am. Assoc. Bovine Pract., Auburn, AL.

Wagner-Storch, A. M., and R. W. Palmer. 2003. Feeding behavior, milking behavior, and milk yields of cows milked in a parlor versus an automatic milking system. J. Dairy Sci. 86:1494-1502.

West, J. W., G. M. Hill, J. M. Fernandez, P. Mandebvu, and B. G. Mullinix. 1999. Effects of dietary fiber on intake, milk yield, and digestion by lactating dairy cows during cool or hot, humid weather. J. Dairy Sci. 82:2455-2465.

West, J. W., B. G. Mullinix, J. C. Johnson, K. A. Ash, and V. N. Taylor. 1990. Effects of bovine somatotropin on dry matter intake, milk yield and body temperature in Holstein and Jersey cows during heat stress. J. Dairy Sci. 73:2896-2906. 